Int. J. Dev. Biol. 56: 473-478 (2012)

doi: $10.1387 / \mathrm{ijdb} .113448 \mathrm{hb}$

\title{
The head organizer in Hydra
}

\author{
HANS R. BODE* \\ Department of Developmental and Cell Biology, University of California, Irvine, CA, USA
}

\begin{abstract}
Organizers and organizing centers play critical roles in axis formation and patterning during the early stages of embryogenesis in many bilaterians. The presence and activity of an organizer was first described in adult Hydra about $\mathbf{1 0 0}$ years ago, and in the following decades organizer regions were identified in a number of bilaterian embryos. In an adult Hydra, the cells of the body column are constantly in the mitotic cycle resulting in continuous displacement of the tissue to the extremities where it is sloughed. In this context, the head organizer located in the hypostome is continuously active sending out signals to maintain the structure and morphology of the head, body column and foot of the animal. The molecular basis of the head organizer involves the canonical Wnt pathway, which acts in a self-renewing manner to maintain itself in the context of the tissue dynamics of Hydra. During bud formation, Hydra's mode of asexual reproduction, a head organizer based on the canonical Wnt pathway is set up to initiate and control the development of a new Hydra. As this pathway plays a central role in vertebrate embryonic organizers, its presence and activity in Hydra indicate that the molecular basis of the organizer arose early in metazoan evolution.
\end{abstract}

KEY WORDS: organizer, axial patterning, canonical Wnt pathway

\section{Introduction}

The organizer plays an early and central role in setting up the structure of developing embryos. In vertebrate embryos a small region on the dorsal side of the prospective mesoderm sets up the dorsal- ventral and anterior-posterior axes. This is illustrated by transplantation of the dorsal lip of the blastopore of an early Xenopus gastrula to the ventral side of a second gastrula. The transplant results in the formation of a second embryonic axis emerging from the ventral side (Harland and Gerhart (1997). This type of experiment has been carried out with a number of vertebrate embryos [e.g. chick, mouse, zebrafish] with similar results [Smith and Schoenwolf (1998). The presence of organizing centers have also been demonstrated in sea urchin embryos (Croce and McClay, 2006) as well as Drosophila embryos [Driever and Nusslein-Volhard (1988), Lehmann and Nusslein-Volhard, (1991) indicating that an organizer, or tissue with organizer activity is common among bilaterians. Thus, most likely this embryonic process / structure arose during metazoan evolution before the appearance of the bilaterians. The evidence for the presence of an organizer in adult Hydra supports this viewpoint. In the following a brief history of the head organizer in Hydra as well as the evidence for the presence of an organizer in adult Hydra, and a summary of the molecular basis of this organizer will be presented.

\section{Historical context of the Hydra head organizer}

The discovery of the role of an organizer in embryonic development is usually associated with Spemann's experiments with newt embryos in 1924 (Spemann \& Mangold, 1924). Evidence for tissue with organizer capacity among metazoans actually appeared earlier. As Howard Lenhoff (1991) pointed out, Ethel Browne (1909) demonstrated the presence of an organizer in the hypostome, which is at the apical end of an adult Hydra (Fig. 1). She isolated a piece of the hypostome and transplanted it to the body column of another Hydra. Within a few days the transplant induced the development of a head with hypostome and tentacles as well as a body column. It never developed a foot, and thus, did not develop as a bud does. To demonstrate that the transplanted tissue "organized" some of the host tissue into forming this second axis, Browne made use of Hydra viridis, a species in which algae live within the epithelial cells. She transplanted a piece of hypostome from Hydra viridis without algae (i.e. unpigmented tissues) to a host with algae (green tissues). The tissue of the induced second axis contained algae indicating that some of the host tissue had been "organized" by the transplant to develop into a head and second

Abbreviations used in this paper: $\mathrm{HO}$, head organizer.

\footnotetext{
*Address correspondence to: Hans R. Bode. Department of Developmental and Cell Biology, University of California, Irvine, Irvine, California 92697, USA. Tel: +1-949-824-5498. Fax: +1-949-824-4709. e-mail: hrbode@uci.edu
}

Final, author-corrected PDF published online: 5 June 2012

ISSN: Online 1696-3547, Print 0214-6282

(C) 2012 UBC Press

Printed in Spain 
axis. By transplanting other parts of a Hydra, Browne (1909) showed that only the hypostome has the capacity to induce a second axis indicating that the organizer was located only in the hypostome. This organizer will be referred to as the head organizer.

Subsequently Mutz (1930) carried out a variety of experiments that supported this view. For example, in one experiment she bisected the body column of a host below the budding zone, and grafted a hypostome onto the base of the body column. This resulted in the formation of a head at the basal end of the host apparently induced by the transplant. Using PelmatoHydra oligactis, Yao (1945) repeated Browne's experiments using a labeled transplant and an unlabeled host, and also showed that the organizer capacity was restricted to the hypostome.

\section{The head organizer in an adult Hydra}

An adult Hydra has the shape of a cylindrical shell consisting of two tissue layers: an ectoderm and an endoderm that make up the head, body column and basal disk (Fig. 1). An organizer is usually associated with the early stages of the development of an embryo. As described above, an adult Hydra has organizer activity (see in this issue Meinhardt, 2012). This organizer is necessary to maintain the structure of an adult Hydra in the context of its tissue dynamics, which are in a steady state of production and loss. All the epithelial cells of both the ectoderm and endoderm of the entire body column are continuously in a mitotic state (David and Campbell, 1972). Yet an adult Hydra remains constant in size and shape. Epithelial tissue in the upper $\sim 1 / 3$ rd of the body column is continuously displaced up the body column (Fig. 1) into the head where it moves out along the tentacles or up the hypostome (Campbell, 1967). When reaching the tips of the tentacles or hypostome, the tissue is sloughed (Campbell, 1967; Otto and Campbell, 1977b). Similarly, epithelial tissue in the lower $\sim 2 / 3$ rds is displaced in a basal direction onto developing buds or further down the column onto the foot. Tissue displaced down to the foot is eventually sloughed on the basal side of the foot (Campbell, 1967), while tissue displaced onto a developing bud is removed from the adult when the bud is mature and detaches from the adult. As a Hydra has no defined lifetime (Martinez, 1998; see in this issue Martinez and Bridge, 2012) this steady state of production and loss of tissue goes on continuously when the animal is fed on a regular basis.

These tissue dynamics require mechanisms for the maintenance in a steady state of the size of the adult animal as well as the morphology of the different regions. The head organizer located in the hypostome plays a central role in maintaining this steady state. As described above, transplantation experiments demonstrated the organizer capacity of the hypostome, and that this capacity is restricted to the hypostome. That the tissue of the second axis, except for the hypostome, was derived from the host was shown by transplanting an unlabeled hypostome to the body column of a host whose tissue was stained (Yao, 1945; Broun and Bode, 2002) or, as mentioned previously, had a natural pigmentation (Browne, 1909). In all of these experiments, the tissue of the induced axis, except for the hypostome, was derived from tissue of the host. When an eighth of the body column is transplanted to a host, a second axis is also formed (MacWilliams, 1983b). However, no induction has occurred as the tissue of the second axis was wholly derived from the transplant (Broun and Bode, 2002). Further, a piece of

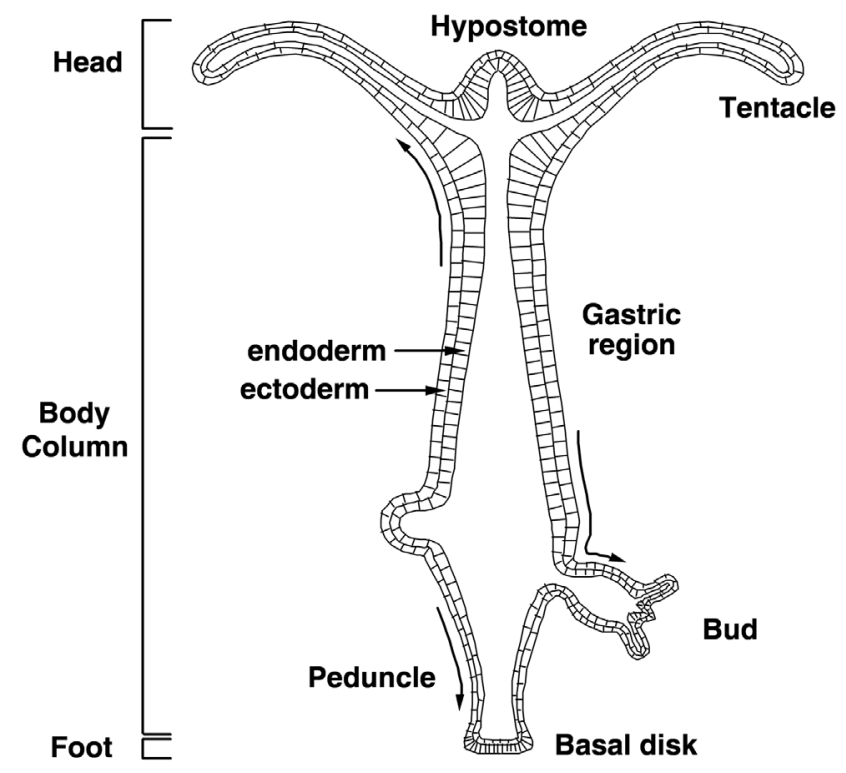

Fig. 1. Longitudinal cross-section of an adult Hydra (Bode, 2001). The regions except for the budding zone are labeled. The two protrusions from the body column are early and late stages of bud development at the apical and basal ends of the budding zone. The arrows indicate the directions of tissue displacement. Cells of the interstitial cell lineage have been omitted.

body column similar in size to a hypostome does not result in the formation of a second axis (Yao, 1945). Thus, of the adult tissue of a Hydra, only the hypostome has the unique capacity for induction of a second axis consisting of head and body column, and hence, has the properties of an organizer.

How much of the hypostomal tissue is involved in the head organizer? Expression of genes, as described in the next section, would indicate that it may be a small part of the hypostome at it's apex. An experiment by Technau et al.,2000) provides evidence consistent with this viewpoint. When several Hydra are dissociated into a suspension of cells that is subsequently centrifuged into a pellet and then placed in Hydra medium, it undergoes the following developmental process. The epithelial cells of the pellet, or aggregate, sort out into a spherical shell consisting of two concentric layers, similar to the organization of these two layers in an intact Hydra (Gierer et al., 1972). The outer layer is composed of the ectodermal epithelial cells and the inner layer of the endodermal epithelial cells. Subsequently, one or more head organizers form, which organize the tissue of the aggregate into one or more animals consisting of head and body column. Technau et al., 2000) added small clusters [10-180 cells] of cells labeled with FITC from regenerating heads to suspensions of dissociated cells and formed aggregates. $50 \%$ of the clusters were subsequently found in developing heads. In contrast, clusters formed from cells of the body column were rarely [2-10\%] found in developing heads. Hence, a relatively small cluster of cells committed to organizer formation is sufficient to set up a head organizer.

A Hydra has a third cell lineage, the interstitial cell lineage consisting of the interstitial cells, which are multipotent stem cells, and their several groups of differentiation products: the nematocytes, neurons, gland cells and gametes (e.g. Bode and David, 1974; see in this issue David, 2012; Hobmayer et al., 2012). This cell lineage 
plays no role in the head organizer as animals in which all the cells of the interstitial cell lineage have been removed behave normally when hand-fed in that their shape and size as well as epithelial cell division and the resulting tissue movements as well as bud formation are normal (Sugiyama and Fujisawa, 1978).

\section{The signals produced by the head organizer}

In the context of the tissue dynamics of an adult Hydra, the head organizer plays a central role in maintaining the structure and morphology of the animal as well controlling bud formation, Hydra's asexual form of reproduction. It does so by producing two signals, the head activator and the head inhibitor. Both diffuse from the hypostome down the body column either among the epithelial cells, or through gap junctions connecting epithelial cells resulting in a graded distribution of each signal along the body column (Wilby and Webster, 1970a,b; MacWilliams, 1983a,b). The head organizer continuously produces the two signals to maintain the two gradients in the context of the tissue dynamics (Fig. 2). The head activation gradient provides the capacity for the initiation of head organizer formation while head inhibition prevents head organizer formation (see in this issue Shimizu, 2012). A new head organizer doesn't form along the upper $2 / 3$ rds of the body column because the level of head inhibitor exceeds that of the head activator (MacWilliams, 1983a). The reverse is true in the budding zone resulting in the initiation of a new head organizer leading to the formation of a new axis, which results in bud formation. It is not clear why a new head organizer does not form in the region between the budding zone and foot. Plausibly the level of head activator may be too low to initiate head organizer formation or that the foot plays an inhibitory role.

The head activator plays a central role in head regeneration When a Hydra is bisected anywhere along the body column of the animal, a head always regenerates at the apical end of the basal part where the level of head activator is highest. The presence of the head activation gradient leads to the formation of a new head organizer in this apical end resulting in head regeneration. Acritical

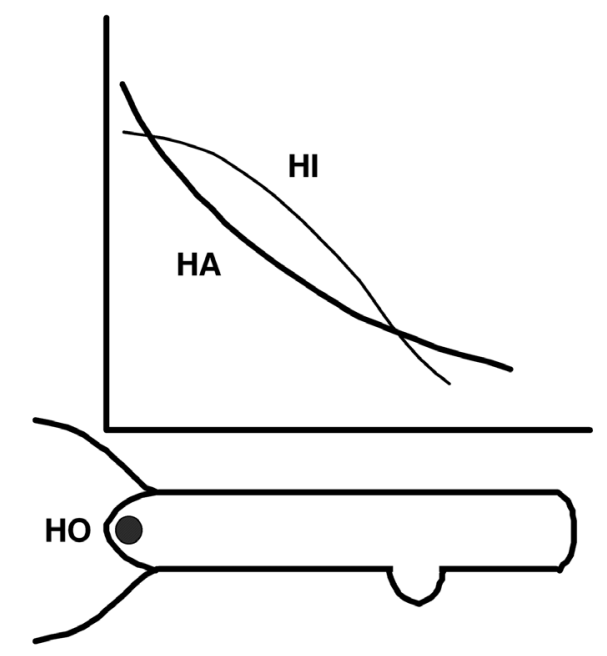

Fig. 2. Axial patterning processes in $\mathbf{H y d r a}$ (Bode, 2009). The head organizer ( $\mathrm{HO}$ ) is located in the hypostome. The head activation (HA) and head inhibition (HI) gradients are graded down the body column. The formation of new axis resulting in bud formation takes place in a location along the body axis where $[H A]>[H I]$. aspect of this process is that the head inhibitor has a short half-life of 2-3 hours (MacWilliams, 1983a) thereby most likely resulting in a higher concentration of head activator than head inhibitor, which leads to head organizer formation and head regeneration. A head does not form at the basal end of the apical part because the head inhibitor produced and continuously transmitted to the body column from the existing head prevents head organizer formation from taking place. The molecular basis of these two signals is not known although there is evidence that head inhibitor is a small molecule that travels through gap junctions (Fraser \& Bode \& Gilula, 1987).

Hence, an adult Hydra has an organizer region with properties similar to that found in vertebrate embryos. No experiments have been carried out to determine if there is an equivalent region in a Hydra embryo. One indication of the presence of such an organizer region in a Hydra embryo is that some of the molecular components of the head organizer are present in these embryos (Frobius et al., 2003) as described in the next section.

\section{Molecular basis of the head organizer}

As mentioned above, in the context of the tissue movements in Hydra, tissue in the hypostome is displaced apically and sloughed at the tip of the hypostome (Campbell, 1967). Since the head organizer is located in the hypostome, it would also be lost were it not continuously renewed. A straightforward means of maintaining the head organizer would be the secretion of a signal by the organizer that would set up a new organizer in a location basal to the existing one. This new organizer would replace the one sloughed at the apex. Such a mechanism would provide for the continuous renewal, and thus, the maintenance of the organizer in the context of the tissue dynamics of the hypostome.

That such a signal exists is supported by the following data involving a hypostome-contact graft. This graft involves making an incision in the body column of a decapitated host Hydra and bringing the hypostome of a second Hydra in contact with the incision (Broun and Bode, 2002). Removal of the graft 48h later results in the induction of a 2 nd axis consisting solely of host Hydra tissue in $89 \%$ of the grafts. As a control, a contact graft made with upper end of the body column placed in contact with the host tissue resulted in only $6 \%$ forming a second axis. The signal transferred in the hypostome-contact graft has a half-life of $\sim 14 \mathrm{~h}$ (Broun and Bode, 2002).

Though the head activator gradient provides a signal for initiating the formation of a new axis, and hence, formation of a head organizer, the signal involved in the hypostome-contact graft is a different signal. Treatment with $\mathrm{Li}+$ blocks an isolated piece of body column from forming a head that is initiated with the presence of head activator in the piece of tissue (Broun and Bode, 2002). However, treatment with $\mathrm{Li}+$ had no effect on the head organizer signaling to set up a second axis in the hypostome contact grafts (Broun and Bode, 2002). This indicates that the signal for setting up the head organizer is different than the head activator signal.

What is the signal that sets up the head organizer? The canonical Wnt pathway appears to be involved in setting up the organizer in Xenopus embryos (Tao et al., 2005). And, probably in a similar manner, beta-catenin plays a critical role in initiating organizer formation in chick (Boettger et al., 2001), mouse (Mohamed et al., 2004) and zebrafish (Kelly et al., 2000) embryos. It also plays a major role in axis specification in sea urchin embryos (Croce 
and McClay, 2006). The expression of several genes involved in the canonical Wnt pathway in Hydra suggested that this pathway plays a role in the Hydra organizer. HyWnt3, TCFand beta-catenin are expressed in the hypostome of the adult (Hobmayer et al., 2000; Broun et al., 2005). Subsequently, it was shown that six other Wnt genes (HyWnt1, HyWnt7, HyWnt9/10a, HyWnt9/10c, HyWnt11, HyWnt16) are expressed in the hypostome (Lengfeld et al., 2009). All are expressed only in the hypostome, although the extent of expression from the apex down to the base of the hypostome varies among them. This is similar to the expression of several Wnt genes that are involved in the canonical Wnt pathway in Xenopus embryos (Croce and McClay, 2006; Croce et al., 2006, Fuerer et al., 2008).

Their involvement in the head organizer in Hydra is illustrated by their expression during bud formation and head regeneration. All seven Wnt genes are expressed at a very early stage of bud formation (Lengfeld et al., 2009), and HyWnt3 is expressed before the begining of bud evagination (Gee and Bode, unpublished results) when the head organizer is being set up (Li and Yao, 1945). In addition, an eighth HyWnt gene, HyWnt2, which is not expressed in the adult hypostome (Lengfeld et al., 2009), is expressed during early stages of bud development. Similarly, during head regeneration the initial appearance of the several HyWnt genes takes place sequentially varying from 1.5 hours to 12 hours following decapitation (Lengfeld et al., 2009). The early expression of HyWnt3 in both bud formation and head regeneration suggests it may play a role in initiating the formation of the head organizer. HyTCF is also expressed during early stages of bud formation and head regeneration (Hobmayer et al., 2000). In Hydra the beta-catenin gene is expressed in the epithelial cells throughout the animal (Broun et al., 2005) as the protein plays a role in the formation of cell membranes. However, it is present in the nuclei of epithelial cells only at the apex of the hypostome where the head organizer is located (Broun et al., 2005). Further, a number of other genes that are involved in the canonical Wnt pathway are also expressed in the hypostome. These include $A P C$, axin, CK1 alpha, CK1 epsilon, Dishevelled, Groucho, GSK-3 and PIN1 (Hobmayer et al., 2000; Gee \& Bode, unpublished results).

\section{Evidence supporting the role of the canonical Wnt pathway in head organizer formation}

Evidence for the role of beta-catenin, and thus, the canonical Wnt pathway in the formation of the head organizer was obtained by treating Hydra with alsterpaullone. This reagent blocks the activity of GSK-3, which is involved in the destruction of beta-catenin (Leost et al., 2000; Bain et al., 2003). Treatment with alsterpaullone raised the level of the beta-catenin protein throughout the animal, which resulted in an increase in the concentration of this protein in the nuclei of cells of the body column (Broun et al., 2005). This treatment also conferred head organizer activity on the tissue of the body column as measured by the standard transplantation experiment (Broun et al., 2005). More direct evidence was obtained by generating a transgenic Hydra in which the beta-catenin gene driven by an actin promoter was continuously and strongly expressed throughout the animal (Gee et al., 2010). The level of expression of this gene throughout the animal was substantially higher than in controls. And, as with the alsterpaullone treatment, the body column of a transgenic animal had acquired head organizer activity as measured by the transplantation experiment. Over time these transgenic Hydra generated additional heads along the body column leading to the formation of several body axes in a single animal (Gee et al., 2010).

Another line of evidence supporting the role of the canonical Wnt pathway in the head organizer involved treating bisected Hydra with recombinant HyWnt3 protein (Lengfeld et al., 2009). The reg-16 strain of Hydra magnipapillata has a reduced capacity to regenerate a head (Sugiyama and Fujisawa, 1977), and unlike a normal Hydra does not express HyWnt3 in the regenerating tip. When bisected animals were treated with the HyWnt3 protein $70 \%$ of them regenerated a head, while in untreated controls only $30 \%$ regenerated a head. Thus, HyWnt3, and most likely the canonical Wnt pathway, were involved in this enhanced ability to set up a head organizer and regenerate a head.

Since the head organizer is located in the hypostome, and tissue of this region is constantly displaced towards its apex and sloughed, the head organizer must be constantly renewed to maintain the steady state morphology of an adult Hydra. As the canonical Wnt pathway is known to operate in a positive feedback loop in mice (Deb et al., 2008) and Drosophila (Heslip et al., 1997), it could be acting in a similar manner in the hypostome. Thus, diffusion of one or more of the Wnt proteins produced in the head organizer in a basal direction could initiate the formation of a new head organizer below the existing organizer. Thereafter, the newly formed head organizer replaces the existing one that is sloughed at the apex. In this manner, the head organizer would remain in a steady state in the context of the continuous displacement of hypostome tissue in an apical direction.

However, this positive feedback loop could be operating at a faster rate than the rate of tissue displacement in an apical direction. In principle this could lead to a continuous formation in a basal direction down through the tentacle zone into the body column of new head organizer tissue, which does not occur. Recently an analysis of the promoter region of the HyWnt3 gene has revealed the presence of two cis-regulatory elements that control the expression of this gene (Nakamura et al., 2011). One of them is positively involved in the expression of the gene thereby facilitating its continuous expression in the hypostome. The second is involved in the repression of the expression of the gene. The latter has been shown to restrict the activity of HyWnt3 to the hypostome, and hence, might be involved in restricting head organizer activity to the hypostome.

As seven Wnt genes are exclusively expressed in the hypostome of an adult Hydra, it is plausible that all or most of them are involved in the formation of the head organizer. However, it is likely that these genes and the canonical Wnt pathway are involved only in the initial steps of the formation of the head organizer. Hydra treated with alsterpaullone results in the transient expression of HyWnt3 and the other six HyWnt genes in the body column for 2-3 days, while the head organizer activity remains at a maximal level for at least six days (Gee et al., 2010). It is unlikely that the maintenance of this activity is due to the presence of HyWnt proteins or beta catenin as Wnt proteins (Cadigan et al., 1998; Strigini and Cohen, 2000) and beta-catenin (Yost et al., 1996; Pai et al., 1997; Guger and Gumbiner, 2000; Weitzel et al., 2004) have half-lives of a few hours in bilaterians. Thus, it is plausible that the canonical Wnt pathway initiates the formation of the head organizer, and that genes downstream of this pathway are involved in the maintenance of the head organizer activity. The genes involved in this process are currently not known. 
Not only is the canonical Wnt pathway involved in maintaining the head organizer in the adult, it is also involved in setting up the organizer during head regeneration and bud formation. During head regeneration the seven HyWntgenes are expressed in a sequence starting with the strong expression of $H y W n t 3$ within 1.5 hours following decapitation. The other six appear sequentially during the first 12 hours following decapitation (Lengfeld et al., 2009). During bud formation all seven are strongly expressed quite early by stage 1 of the budding process. In addition, HyWnt3 is expressed even earlier before any visible sign of bud formation is apparent (Gee and Bode, unpublished result). The earlier expression of HyWnt3 compared to the other HyWnt genes during both developmental processes suggests that it may play a role in initiating head organizer formation. The timing of expression during bud formation indicates that expression of the canonical Wnt pathway precedes the formation of the head organizer. By transplanting the apical ends of developing buds at different stages, Li and Yao (1945) demonstrated that the head organizer developed slowly during bud development. By stage 3 [using Campbell's stages of bud development (Otto and Campbell, 1977a) $30 \%$ of the apical ends of the developing buds could induce a second axis. This rose to $80 \%$ by stage 5 . This rise in the head organizer capacity in the developing bud takes place distinctly later than the expression of the HyWnt genes, which are all expressed by stage 1, which is consistent with HyWnt genes and the canonical Wnt pathway playing a role in setting up the head organizer.

Since the organizer or organizing centers play a critical role in establishing the axes and structures of developing embryos among bilaterians, a final question deals with the issue of an organizer in Hydra embryos. Currently there is no direct evidence for the presence of an organizer in Hydra embryos. Assuming that such an organizer exists, the question arises as to its molecular basis. Frobius et al.,2003) have shown that some of the genes [TCF, beta-catenin, Frizzled] of the canonical Wnt pathway are expressed in very early stage embryos, which is at least consistent with the idea that this pathway plays a role in the early organization of a Hydra embryo.

In summary, the canonical Wnt pathway plays a central role in setting up the head organizer as well as maintaining it in the steady state tissue dynamics of an adult $H y d r a$. The activity of this pathway in Hydra also provides evidence that the role of the canonical Wnt pathway in organizer activity arose quite early in metazoan evolution and was passed on to deuterostomes among the bilaterians.

\section{Future perspectives}

To gain a more complete understanding of the activity, molecular basis and evolution of the organizer in metazoan embryos, it will be useful to study this structure in more species. Given Hydra's early appearance in metazoan evolution, gaining a more complete understanding of the head organizer in Hydra can contribute to this effort. As mentioned above, an adult Hydra has several characteristics that are useful for this endeavor. These include the following.

[a] A Hydra has a very simple structure with few cell types.

[b] The tissue dynamics are in a steady state of production and loss requiring the continuous presence and activity of the head organizer. Thus, one need not examine particular stages of embryo development to investigate aspects of organizer development and activity as any adult $H y d r a c a n$ be used to study the head organizer. [c] Because of its simple structure, transparency, and a detailed knowledge of the cell types and their distribution throughout an adult Hydra, a great deal of information about the genes active in the head organizer can be gained by simply carrying out in situ hybridization assays on fixed intact adult animals.

[d] Because of its simple structure whole Hydra can be treated with compounds, such as alsterpaullone, that promote head organizer formation throughout most of the body column providing another tool for examining the nature and molecular composition of the head organizer.

[e] The canonical Wnt pathway, which plays a central and critical role in vertebrate embryonic organizers, is active in the Hydra head organizer.

[f] Similar studies on the sequence of appearance of these genes involved during the development of the head organizer can be carried out during the bud formation and during head regeneration.

[g] The genome of Hydra magnipapillata, the species of Hydra used for organizer studies, has been sequenced (Chapman et al., 2010). Thus, one can identify genes in Hydra that are homologues of genes involved in organizer activity in other metazoans and examine their possible role in the activity of the head organizer. A large EST project carried out several years ago provides the cDNAs for many of these candidate genes.

[h] The recently developed ability to generate transgenic Hydra (Wittlieb et al., 2006) provides a powerful tool for manipulating specific genes, which thereby provides a means for examining the molecular details of the head organizer.

The one plausible weakness of Hydra as a system to study the molecular basis and activity of an organizer is that the head organizer has been exclusively studied in adult Hydra while organizers in other metazoans are studied in the developing embryo. Knowledge about Hydra embryos is fairly limited as they have not been studied that much. Thus, it is plausible that there could be differences in organizer formation, characteristics, and molecular components that could muddy the waters in understanding the evolution of the molecular biology of the organizer. Although the presence of components of the canonical Wnt pathway in early stage embryos (Frobius et al., 2003) suggests the organizer in Hydra embryos could have a similar basis as the head organizer. In addition, the ability to generate transgenic Hydra provides an approach for directly examining the role of genes of this pathway in the formation of the organizer in a Hydra embryo.

\section{References}

BAIN, J., MCLAUCHLAN, H., ELLIOTT, M., COHEN, P. (2003). The specificities of protein kinase inhibitors: an update. Biochem J 371: 199-204.

BODE, H.R., DAVID, C.N. (1978). Regulation of a multipotent stem cell, the interstitial cell of hydra. Prog Biophys Mol Biol 33: 189-206.

BOetTGeR, T., KNOETGEN, H., WITTLER, L., KESSEL, M. (2001). The avian organizer. Int J Dev Biol 45: 281-287.

BODE, H.R. (2001). The role of Hox genes in axial patterning in Hydra. Am Zool 41: $621-628$.

BODE, H.R. (2009). Axial patterning in Hydra. CSH Perspect Biol 1: a000463.

BROUN, M., BODE, H.R. (2002). Characterization of the head organizer in Hydra. Development 129: 875-884.

BROUN, M., GEE, L., REINHARDT, B., BODE, H.R. (2005). Formation of the head organizer in hydra involves the canonical Wnt pathway. Development 132:2907-2916.

BROWNE, E.N. (1909). The production of a new hydranth in hydra by insertion of small grafts. J Exp Zool 7: 1-37. 
CADIGAN, K.M., FISH, M.P, RULIFSON, E.J., NUSSE, R. (1998). Wingless repression of Drosophila frizzled 2 expression shapes the Wingless morphogen gradient in the wing. Cell 93: 767-777.

CAMPBELL, R.D. (1967). Tissue dynamics of steady state growth in Hydra littoralis. II. Patterns of tissue movement. J Morphol 121: 19-28.

CHAPMAN, J.A., KIRKNESS, E.F., SIMAKOV, O., HAMPSON, S.E., MITROS, T., WEINMAIER, T., RATTEI, T., BALASUBRAMANIAN, P.G., BORMAN, J., BUSAM, et al. (2010). The dynamic genome of Hydra. Nature 464: 592-596.

CROCE, J.C., MCCLAY, D.R. (2006). The canonical Wnt pathway in embryonic axis formation. Semin Cell Dev Biol 17: 168-174.

CROCE, J.C., WU, S.Y., BYRUM, C., XU, R., DULOQUIN, L., WIKRAMANAYAKE, A.H., GACHE, C., MCCLAY, D.R. (2006). A genome-wide survey of the evolutionarily conserved Wnt pathways in the sea urchin Strongylocentrotus purpuratus. Dev Biol 300: 121-131.

DAVID, C.N., CAMPBELL, R.D. (1972). Cell cycle kinetics and development of Hydra attenuata. I. Epithelial cells. J Cell Sci 11: 557-568.

DAVID, C.N. (2012). Interstitial stem cells in Hydra: multipotency and decision-making. Int J Dev Biol 56: 489-497.

DEB, A., DAVIS, B.H., GUO, J., NI, A., HUANG, J., ZHANG, Z., MU, H., DZAU VJ. (2008). SFRP2 regulates cardiomyogenic differentiation by inhibiting a positive transcriptional autofeedback loop of Wnt3a. Stem Cells 26: 35-44.

DRIEVER, W., NUSSLEIN-VOLHARD, C. (1988). A gradient of Bicoid protein in Drosophila embryos. Cell 54: 83-93.

FRASER, S.E., GREEN, C.R., BODE, H.R., GILULA, N.B. (1987). Selective disruption of gap junctional communication interferes with a patterning process in Hydra. Science 237: 49-55.

FROBIUS, A.C., GENIKOVICH, G., ANTON-ERXLEBEN, F., BOSCH, T.C. (2003). Expression of developmental genes during early embryogenesis of Hydra. Dev Genes Evol 213: 445-455.

FUERER, C., NUSSE, R., TEN BERGE, D. (2008). Wnt signalling in development and disease. EMBO Rep 9: 134-388.

GEE, L., HARTIG, J., LAW,.L, WITTLIEB, J., KHALTURIN, K., BOSCH, T.C., BODE, H.R. (2010). Beta-catenin plays a central role in setting up the head organizer in hydra. Dev Biol 340: 116-124.

GIERER, A., BERKING, S., BODE, H., DAVID, C.N., FLICK, K., HANSMANN, G., SCHALLER, H., TRENKNER, E. (1972). Regeneration of hydra from reaggregated cells. Nature New Biol. 239: 98-101.

GUGER, K.A., GUMBINER, B.M. (2000). A mode of regulation of beta-catenin signaling activity in Xenopus embryos independent of its levels. Dev Biol 223: 441-448.

HARLAND, R., GERHART, J. (1997). Formation and function of Spemann's organizer. Ann Rev Cell Dev Biol 13: 611-667.

HESLIP, T.R., THEISEN, H., WALKER, H., MARSH, J.L. (1997). Shaggy and dishevelled exert opposite effects on Wingless and Decapentaplegic expression and on positional identity in imaginal discs. Development 124: 1069-78.

HOBMAYER, B., RENTZSCH, F., KUHN, K., HAPPEL, C.M., VON LAUE, C.C., SNYDER, P., ROTHBACHER, U., HOLSTEIN, T.W. (2000). WNT signalling molecules act in axis formation in the diploblastic metazoan Hydra. Nature 407: 186-189.

HOBMAYER, B., JENEWEIN, M., EDER, D., GLASAUER, S., GUFLER, S., HARTL, M. and SALVENMOSER, W. (2012). Stemness in Hydra - a current perspective. Int $J$ Dev Biol 56: 509-517.

KELLY, C., CHIN, A.J., LEATHERMAN, J.L., KOZLOWSKI, D.J., WEINBERG, E.S. (2000). Maternally controlled (beta)- catenin-mediated signaling is required for organizer formation in the zebrafish. Development 127: 3899-3911.

LEHMANN, R., NUSSLEIN-VOLHARD, C. (1991). The maternal gene nanos has a central role in posterior pattern formation of the Drosophila embryo. Develop ment 112: 679-691.

LENGFELD, T., WATANABE, H., SIMAKOV, O., LINDGENS, D., GEE, L., LAW, L., SCHMIDT, H.A., OZBEK, S., BODE, H., HOLSTEIN, T.W. (2009). Multiple Wnts are involved in Hydra organizer formation and regeneration. Dev Bio/330: 186-199.

LENHOFF, H. (1991). Ethel Browne, Hans Spemann, and the Discover of the Organizer Phenomenon. Biol Bull 181: 72-80.

LEOST, M., SCHULTZ, C., LIN,K A., WU, Y.Z., BIERNAT, J., MANDELKOW, E.M., BIBB, J.A., SNYDER, G.L., GREENGARD, P., ZAHAREVITZ, D.W., GUSSIO, R., SENDEROWICZ, A.M., SAUSVILLE, E.A., KUNICK, C., MEIJER, L. (2000). Paullones are potent inhibitors of glycogen synthase kinase-3beta and cyclindependent kinase 5/p25. Eur J Biochem 267: 5983-94.

LI, H.P., YAO, T. (1945). Studies on the organizer problem in Pelmatohydra oligactis:
III Bud induction by developing hypostome. J Exp Biol 21: 155-160

MACWILLIAMS, H.K. (1983a). Hydra transplantation phenomena and the mechanism of hydra head regeneration. I. Properties of head inhibition. Dev Biol 96: 217-38.

MACWILLIAMS, H.K. (1983b). Hydra transplantation phenomena and the mechanism of hydra head regeneration. II. Properties of head activation. Dev Bio/96: 239-257.

MARTINEZ, D.E. (1998). Mortality patterns suggest lack of senescence in hydra. Exp Gerontol 33: 217-225.

MARTINEZ, D., BRIDGE, D. (2012). Hydra, the everlasting embryo, confronts aging. Int J Dev Biol 56: 479-487.

MEINHARDT, H. (2012) Modeling pattern formation in hydra: a route to understanding essential steps in development. Int. J. Dev. Biol. 56: 447-462.

MOHAMED, O.A., CLARKE, H.J., DUFORT, D. (2004). Beta-catenin signaling marks the prospective site of primitive streak formation in the mouse embryo. Dev Dyn 231: 16-24.

MUTZ, E. (1930). Transplantationsversuche an Hydra mit besonderer berucksichtigung der Induktion, Regionalitat und Polaritat. Arch Entwicklungsmechanik Org 121: $210-271$

NAKAMURA, Y., TSIAIRIS, C.O., OZBEK, S., HOLSTEIN, T. (2011). Autoregulatory and repressive inputs localize Hydra Wnt3 to the head organizer. Proc Nat Acad Sci USA 108: 9137-9142.

OTTO, J.J., CAMPBELL, R.D. (1977a). Budding in Hydra attenuata: bud stages and fate map. J Exp Zool 200: 417-428.

OTTO, J.J., CAMPBELL, R.D. (1977b). Tissue economics of Hydra: regulation of cell cycle, animal size and development by controlled feeding rates. J Cell Sc 28: 117-137.

PAI, L.M., ORSULIC, S., BEJSOVEC, A., PEIFER, M. (1997). Negative regulation of Armadillo, a Wingless effector in Drosophila. Development 124: 2255-2266.

SHIMIZU, H. (2012). Transplantation analysis of developmental mechanisms in Hydra. Int J Dev Biol 56: 463-472.

SMITH, J.L., SCHOENWOLF, G.C. (1998). Getting organized: new insights into the organizer of higher vertebrates. Curr Top Dev Biol 40: 79-110.

SPEMANN, H., MANGOLD, H. (1924). Uber Induktion von Embryonanlagen durch Implantation artfremder Organisatoren Arch Mikr Anat Entw Mech 100: 599-638.

STIGINI, M., COHEN, S.M. (2000). Wingless gradient formation in the Drosophila wing. Curr Biol 10: 293-300.

SUGIYAMA, T., FUJISAWA, T. (1977). Genetic analysis of developmental mechanisms in Hydra. III. Characterization of a regeneration deficient strain. J Embryol Exp Morphol 42: 65-77.

SUGIYAMA, T., FUJISAWA, T. (1978). Genetic analysis of developmental mechanisms in Hydra. II. Isolation and characterization of an interstitial cell-deficient strain. J Cell Sci 29: 35-52.

TAO, Q., YOKOTA, C., PUCK, H., KOFRON, M., BIRSOY, B., YAN, D., ASASHIMA, M., WYLIE, C.C., LIN, X., HEASMAN, J. (2005). Maternal wnt11 activates the canonical wnt signaling pathway required for axis formation in Xenopus embryos. Cell 120: 857-71.

TECHNAU, U., CARMER VON LAUE, C., RENTZSCH, F., LUF,T S., HOBMAYER, B., BODE, H.R., HOLSTEIN, T,W. (2000). Parameters of self-organization in Hydra aggregates. Proc Natl Acad Sci USA 97: 12127-12131.

WEITZEL, H.E., ILLIES, M.R., BYRUM, C.A., XU, R., WIKRAMANAYAKE, A.H., ETTENSOHN, C.A. (2004). Differential stability of beta-catenin along the animalvegetal axis of the sea urchin embryo mediated by dishevelled. Development 131: 2947-2956.

WILBY, O.K., WEBSTER, G. (1970a). Experimental studies on axial polarity in hydra. $J$ Embryol Exp Morph 24: 595-613

WILBY, O.K., WEBSTER, G. (1970b). Studies on the transmission of hypostome inhibition in hydra. J Embryol Exp Morph 24: 583-593.

WITTLIEB, J., KHALTURIN, K., LOHMANN, J.U., ANTON-ERXLEBEN, F., BOSCH, T.C. (2006). Transgenic Hydra allow in vivo tracking of individual stem cells during morphogenesis. Proc Natl Acad Sci USA. 103: 6208-6211.

YAO, T. (1945). Studies on the organizer problem in Pelmatohydra oligacts. I. The induction potency of the implants and the nature of the induced hydranth. $J$ Exp Biol 21: 147-150.

YOST, C., TORRES, M., MILLER, J.R., HUANG, E., KIMELMAN. D., MOON, R.T. (1996). The axis-inducing activity, stability, and subcellular distribution of betacatenin is regulated in Xenopus embryos by glycogen synthase kinase 3. Genes Dev 10:1443-1454. 


\section{Further Related Reading, published previously in the Int. J. Dev. Biol.}

An organizing region in metamorphosing hydrozoan planula larvae - stimulation of axis formation in both larval and in adult tissue Melanie Stumpf, Britta Will, Karola Wittig, Jennifer Kasper, Benjamin Fischer, Jürgen Schmich, Stefanie Seipp and Thomas Leitz Int. J. Dev. Biol. (2010) 54: 795-802

Wnt signaling in hydroid development: ectopic heads and giant buds induced by GSK-3beta inhibitors

Werner Müller, Uri Frank, Regina Teo, Ofer Mokady, Christina Guette and Günter Plickert Int. J. Dev. Biol. (2007) 51:211-220

Patterning a multi-headed mutant in Hydractinia: enhancement of head formation and its phenotypic normalization

Werner A Müller, Regina Teo and Frank Möhrlen

Int. J. Dev. Biol. (2004) 48: 9-15

Pattern regulation properties of a Hydra strain which produces additional heads along the body axis

$S$ Zeretzke and S Berking

Int. J. Dev. Biol. (2001) 45: 431-439

Analysis of a Hydra mutant which produces extra heads along its body axis $S$ Zeretzke and S Berking Int. J. Dev. Biol. (1996) 40: S271-S271

5 yr ISI Impact Factor $(2010)=2.961$

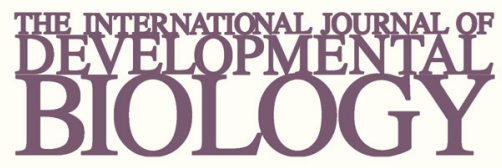

Volume 54 Nos. 6/7
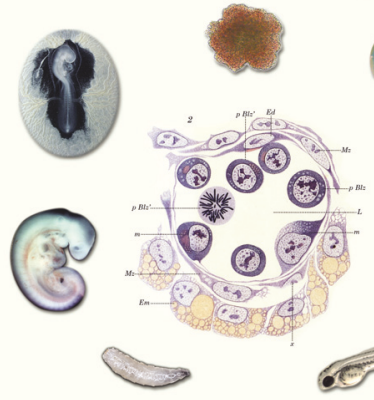

Developmental Hematopoiesis
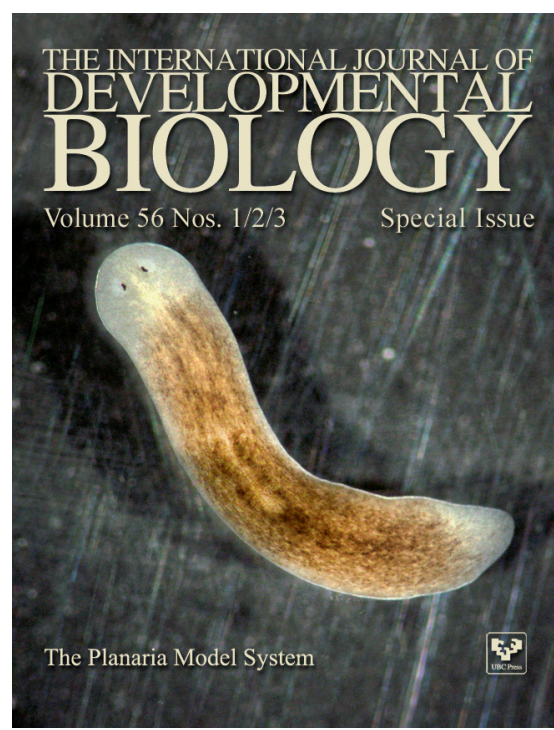
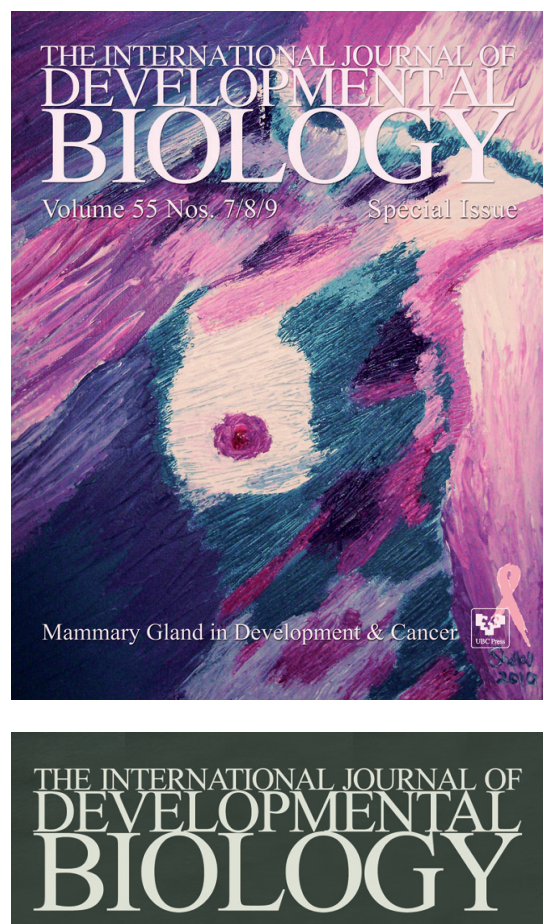

Volume 55 Nos. $4 / 5$

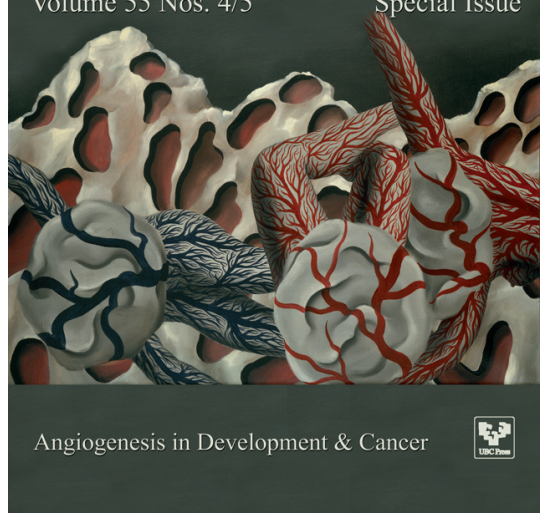

